\title{
MONITORING KASUS TUBERCULOSIS BERBASIS GOOGLE EARTH
}

\author{
Bahtera Bin David Purba \\ Institut Kesehatan Deli Husada, Jl. Besar Deli Tua, Deli Serdang \\ Email: bahterabd@gmail.com
}

\begin{abstract}
ABSTRAK
Tuberculosis is one of the world's health problems including in Indonesia. In 2017 the number of new tuberculosis cases in the Deli Tua Health Center area reached 143 cases with a success rate of $76 \%$ and MDR TB reaching $15 \%$. This decrease in cases was caused by improper drug uptake and MDR TB medication dosage errors and non-compliance with taking medication. To overcome the problem, Google Earth mapping and calendar documentation were applied. The results of the implementation show that there is a difference which means the completeness of treatment before and after the intervention with $\mathrm{RR}=2.21 ; 95 \% \mathrm{CI}: 1.32-3.69$, cure rate for tuberculosis cases with $\mathrm{RR}=1.87 ; 95 \% \mathrm{CI}: 1.17-2.99$, the dropout rate for treatment with RR $=1.77 ; 95 \% \mathrm{CI}: 1.07-2.95$, and mortality rate. Google Earth-based tuberculosis case intervention increased treatment completeness by $18.3 \%$, improved tuberculosis case recovery by $15.9 \%$, decreased tuberculosis case dropout rates by $12.5 \%$ and decreased tuberculosis case fatality rates by $4.4 \%$. It was concluded that the Google Earth-based tuberculosis case monitoring system was effectively implemented in the work area of the Public health center in Deli Tua. It is recommended to use of Google Earth-based tuberculosis monitoring system.
\end{abstract}

Keyword: Tuberculosis, Maping Google Earth, Dokumentasi Kalender, Kasus Tuberculosis

\section{Pendahuluan}

Puskesmas merupakan penyedia pelayanan kesehatan masyarakat (health provider) dan penduduk diwilayah kerjanya adalah pemanfaat pelayaan kesehatan (health consumer). Tahun 2017 angka kasus tuberculosis (TB) baru (TB ternotifikasi) di wilayah kerja Puskesmas Deli Tua mencapai 143 kasus dengan angka success rate $76 \%$ dan TB MDR mencapai 15\%. Di kabupaten Deli Serdang, $87 \%$ kasus TB termasuk golongan keluarga miskin dengan pendapatan kurang dari 2,5 juta perbulan (Athena, 2014).

Tuberculosis adalah salah satu masalah kesehatan dunia termasuk di Indonesia. WHO menempatkan Indonesia di urutan kedua kasus tuberculosis dengan jumlah kasus 1,02 juta kasus atau 395 per 100 ribu penduduk dengan kasus TB MDR (Multi Drug Resistence) sebesar 32 ribu kasus atau 12 kasus per 100 ribu penduduk (WHO, 2017). Tuberculosis adalah salah satu penyakit yang disebabkan oleh kuman micobacterium tuberculosis yang dapat menular dengan mengeluarkan droplet nuklei ke udara melalui batuk dan bersin. Menurut CDC penularan TB dapat dikontrol melalui pengobatan, kontrol lingkungan, dan kontrol droplet nuclei (CDC, 2014). Kasus tuberculosis cenderung tidak berdaya secara fisk karena sifat penyakit yang kronis. Ketidak berdayaan secara fisik menyebabkan ketidak berdayaan ekonomi, psikologi, dan sosial karena tingginya stigma dari masyarakat yang menganggap tuberculosis 
adalah penyakit yang tidak dapat disembuhkan (WHO, 2017).

Pengambilan obat tidak tepat waktu dan kesalahan dosis pengobatan TB MDR berdampak pada perilaku ketidakpatuhan minum obat yang dapat berkontribusi menyebabkan kejadian gagal kasus TB dan TB MDR. Perilaku ketidakpatuhan minum obat pada pasien TB aktif dan TB MDR dapat terjadi dengan berbagai faktor penyebab. Tuberculosis adalah penyakit yang berisfat kronis dan baru dapat disembuhkan setelah enam bulan mengonsumsi obat. Durasi waktu pengobatan yang lama membuat pasien merasa bosan terhadap pengobatan, effek samping obat, lupa minum obat, faktor self efficacy, dan faktor self monitoring (Martin, 2015). Self monitoring adalah unsur penting dalam pengobatan tuberculosis yang melibatkan coping terhadap berbagai regulasi pengobatan yang bersifat kronis (Petricia, 2014). Self monitoring merupakan kesediaan individu melakukan sesuatu hal untuk kepentingan diri sendiri tanpa diawasi oleh orang lain dan disadari sebagai suatu kebutuhan dalam diri individu (Green, 2013). Dokumentasi kalender merupakan pendokumentasian aktivitas minum obat, kontrol lingkungan, dan kontrol droplet nuclei berdasarkan urutan waktu dalam pengobatan TB merupakan esensi self monitoring dalam penanggulangan TB (Petricia, 2014).

TB MDR adalah kasus TB dengan kuman micobacterium yang telah mengalami resistensi terhadap antibiotic. TB MDR menyebabkan pasien TB menjalani proses pengobatan level kedua dengan dosis antibiotic yang lebih tinggi dari level pertama. Kesalahan dosis pengobatan pada kasus TB MDR disebabkan karena pemeriksaan sputum kasus TB puskesmas dilakukan dengan microskop manual. Jenis alat pemeriksaan ini tidak mampu untuk mendiagnosa kasus TB MDR. Diagnosa TB MDR perlu pemeriksaan khusus dengan metode PCR (Xpert MTB/RIF), pemeriksaan biakan serta uji kepekaan kuman (Drugs sensitivity test/DST) terhadap obat TB (Dinas Kesehatan, 2017).

Selama ini, penanganan kasus TB di Puskesmas dijalankan berdasarkan strategi DOTS (Directly Observed Treatment Short Course). Program DOTS yang dijalankan di Puskesmas adalah salah satu program pengontrolan pengobatan TB dengan tujuan pengobatan pasien TB secara tuntas (success rate $100 \%$ ) dan zero kasus TB baru tahun 2030 (WHO, 2017).

Masalah spesifik yang dihadapi oleh Puskesmas saat ini dalam penanggulangan kasus TB adalah kesulitan dalam memetakan kasus TB secara geografis. Hingga saat ini, sistem monitoring kasus TB masih dilakukan secara manual oleh PMO (Pengawas Minum Obat) dan belum ada inovasi teknologi yang tepat guna untuk menyelesaikan berbagai masalah persoalan monitoring kasus tuberculosis.

Keefektifan penerapan teknologi maping elektronik dalam penanggulangan TB telah ditemukan oleh Purba dalam penelitiannya yang menemukan bahwa ketepatan waktu penyembuhan TB aktif dan MDR berbeda bermakna pada puskesmas yang menggunakan metode monitoring berbasis google earth dibandingkan dengan puskesmas dengan metode monitoring manual (Dinas Kesehatan, 2017). Hasil penelitian Athena tentang efektifitas monitoring kasus TB berbasis Geografic Information System (GIS) menunjukan peningkatan kepatuhan minum obat pasien tuberculosis (Athena, 2014). WHO 2013 juga menemukan sistem surveilans berbasis pemetaan lebih efektif dalam mengontrol penyakit infeksi dibandingkan sistem non pemetaan.

Hasil penelitian Adamou menemukan pentingnya pemetaan kasus penyakit-penyakit tropis di Indonesia (Ho-Lin, 2012). Pemetaan kasus tuberculsosis merupakan alat monitoring yang efektif sistem survelans tuberculosis. Pemetaan berbasis teknologi maping juga telah 
ditemukan oleh berbagai organisasi kesehatan dunia seperti Epi-info (WHO, 2013), Health Maper (2015), E2 Google earth (Ho-Lin, 2012).

Hasil penelitian Purba menemukan perbedaan yang bermakna $(R R=4,3)$ pasien $T B$ dengan dokumentasi kalender dibandingkan dengan pasien TB tanpa dokumentasi kalender (Petricia, 2014). Dokumentasi kalender adalah salah satu alat self-monitoring kasus tuberculosis tanpa adanya pengawas menelan obat. Ryan dalam penelitiannya juga menemukan pengaruh self monitoring terhadap self-recorded dan selanjutnya berkontribusi terhadap kepatuhan minum obat, kontrol lingkungan, dan kontrol droplet nuclei. Mackey menemukan bahwa self recorded pengobatan individu meningkatkan kualitas data pasien yang penting untuk meningkatkan kualitas surveilans data terutama pada penyakit-penyakit kronis yang memerlukan kepatuhan pengobatan (Mackey, 2016).

Pemetaan kasus tuberculosis dalam populasi perlu diterapkan selama 6 bulan (1 periode pengobatan) dengan alat pengumpul data adalah dokumentasi kalender. Data dikumpulkan dari dokumentasi kalender yang dibagikan kepada pasien 1 kali dalam sebulan. Dokumentasi kalender memberikan data tentang perilaku pasien TB tentang kepatuhan menelan obat, kontrol lingkungan, dan kontrol droplet nuclei. Pemetaan kasus ke dalam software google earth diklasifikasikan dengan kategori risiko tinggi, risiko rendah, dan tidak berisiko. Gambaran pemetaan ini divisualisasikan dalam peta wilayah kerja secara terus menerus sehingga dapat diperoleh sumber penularan tuberculosis dari waktu ke waktu.

\section{METODE}

Kabupaten Deli Serdang adalah salah satu kabupaten dari 33 kabupaten yang ada di Provinsi Sumatera Utara. Pada bulan Januari tahun 2019, Puskesmas Deli Tua ditetapkan sebagai puskesmas dengan intervensi sistem monitoring kasus tuberculosis berbasis google earth. Penerapan sistem ini dilakukan selama 6 bulan (Januari-April 2019). Dengan sistem pencatatan data berbasis dokumentasi kalender dari pasien tuberculosis.

Populasi dalam penelitian ini adalah pasien tuberculosis di puskesmas Deli Tua. Jumlah sampel ditetapkan non random sebanyak 99 kasus tuberculosis yang didasarkan pada formula Lameshow dalam sampling minimum untuk estimasi. Penentuan kontrol ditentukan berdasarkan tetangga terdekat dari 1 Januari sampai 31 Desember 2018 sebanyak 167 kasus.

Jumlah kasus tuberculosis tahun 2018 ditetapkan sebagai data pembanding. Sistem monitoring kasus tuberculosis di puskesmas Deli Tua tahun 2018 dilakukan secara manual. Penentuan kohort penelitian dimulai sejak bulan Januari hingga Oktober tahun 2019.

Desain studi yang dilakukan dalam penelitian ini adalah desain quasi eksperiment before and after. Kasus tuberculosis di Puskesmas Deli Tua 2019 ditetapkan sebagai kelompok Intervensi. Sedangkan kasus tuberculosis dalam durasi kohorot 1 tahun (terhitung 1 Januari sampai 31 Desember 2018) ditetapkan sebagai kelompok kontrol. Perbandingan intervensi-kontrol ditetapkan $1: 2$ un-macth untuk kategori kasus tuberculosis baru.

Setelah waktu kohort berakhir kualitas data dan outcome program TB diukur. Kemudian hasilnya dibandingkan dengan kelompok kontrol yang diukur dengan risiko relative (RR).

Penelitian ini dilakukan dengan menggunakan software google earth yang diinstal dari google. Google earth digunakan untuk memetakan kasus secara visual bedasarkan titik latitude dan longitude. Alat pengumpul data yang digunakan adalah dokumentasi kalender. Dokumentasi kalender berisi tentang perilaku menelan obat, kontrol lingkungan dan kontrol droplet nuclei pasien TB. Dokumentasi kalender diisi oleh pasien TB diberikan pada saat mengambil obat dan 


\begin{tabular}{l|r|c}
\hline Jurnal Penelitian Kesmasy & Vol. 2 No. 1 & Edition: May - October 2019 \\
\hline \multirow{2}{*}{ Received: 07 October 2019} & http://ejournal.delihusada.ac.id/index.php/JPKSY & Accepted: 22 October 2019 \\
\cline { 2 - 3 } & Revised: 12 October 2019 &
\end{tabular}

dipulangkan pada saat mengambil obat pada bulan berikutnya.

Proses pemetaan kasus tuberculosis dimulai dari install software google earth. Data dari ndokumentasi kalender yang dikumpulkan dari pasien TB kemudian di input kedalam software google earth dengan kategori: 1) merah (risiko tinggi tidak patuh), kuning (risiko rendah tidak patuh menelan obat), dan hijau (tidak ada risiko tidak patuh).

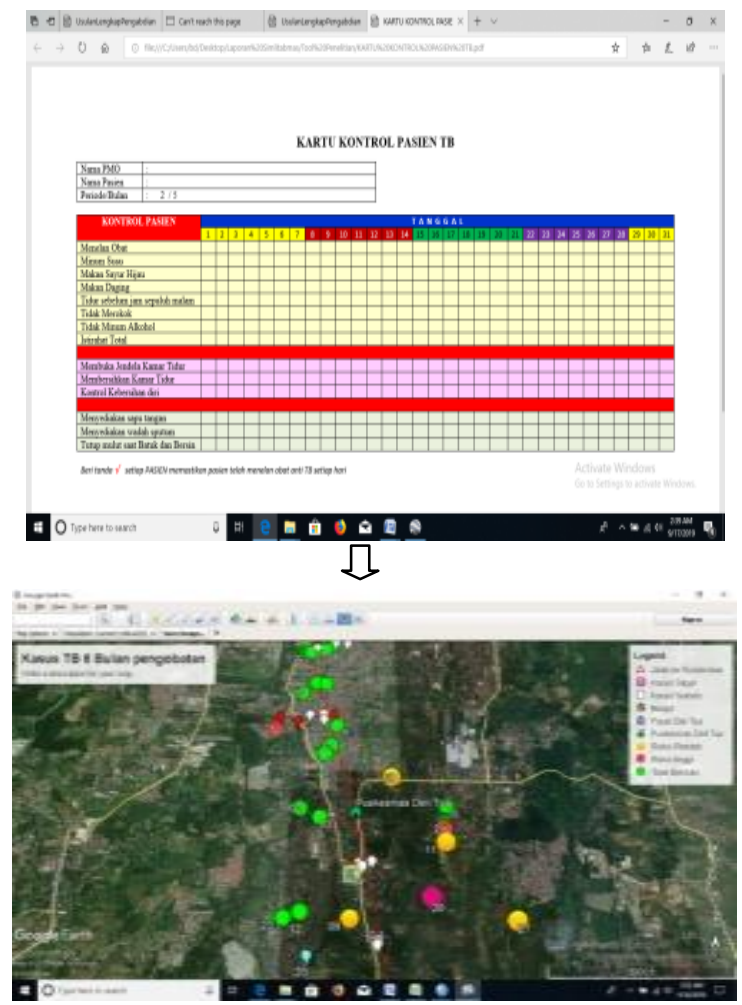

Gambar 1. Proses Pemetaan Kasus

Tuberculosis Berbasis Google Earth

Instrumen data adalah kuesioner yang diadopsi dari CDC guide control tuberculosis 2013. Kuesioner yang digunakan dalam penelitian ini telah diuji coba terlebih dahulu pada populasi yang memiliki karakteristik hampir sama. Uji validitas dan reliabilitas dilakukan terhadap 30 kasus tuberculosis di puskesmas terdekat. Uji validitas dilakukan dengan menggunakan Item Corrected Corelation (ICC) dan uji reliabilitas dengan meggunakan metode Cronbach's Alpha. Kuesioner dikatakan valid jika ICC $\geq 0,5$ dan Cronbach's Alpha $\geq 0,6$.
Metode analisa data dilakukan dengan tiga tahapan yaitu analisa univariat, bivariat, dan multivariate. Analisa bivariat dilakukan dengan menggunakan uji MC nemar dan Exact Fisher pada taraf nyata $a=0,05$. Analisa multivariate dilakukan dengan menggunakan uji logistic regression pada taraf nyata $\mathrm{a}=0,05$. Keputusan statitistik dinyatakan pada tolak Ho jika $p<0,05$.

\section{HASIL DAN PEMBAHASAN}

Puskesmas Delitua adalah salah satu puskesmas pusat di kabupaten Deli Serdang, Provinsi Sumatera Utara yang memberikan layanan kesehatan dasar dengan 23 program kerja. Puskesmas Delitua terletak di Jl. Kesehatann dan hingga saat ini melayani sekitar 28.197 jiwa penduduk. Secara geografis wilayah kerja Puskesmas Deli Tua berbatasan dengan Kecamatan Medan Johor di sebelah Utara, Kecamatan Patumbak di sebelah Timur, Kecamatan Namorambe di sebelah Barat, dan Kecamatan Biru-Biru di sebelah Selatan.

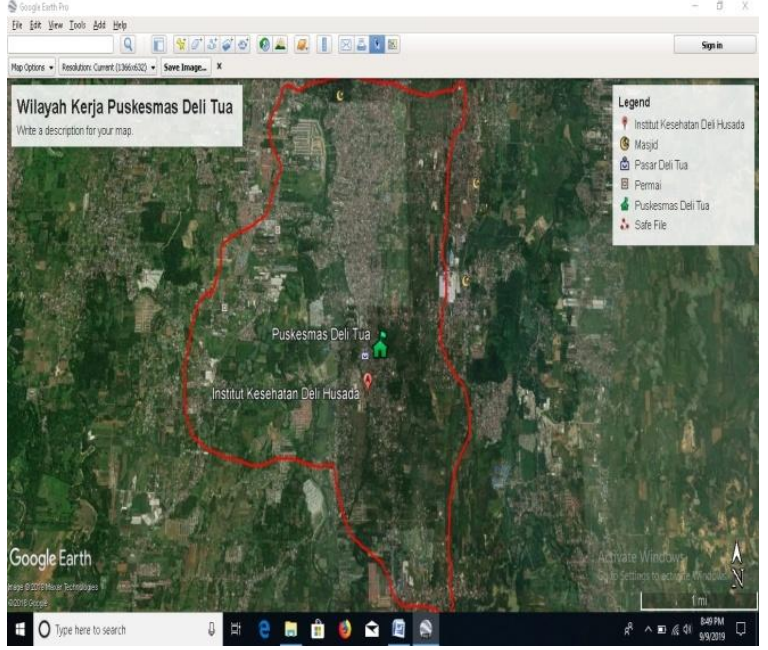

Gambar 2. Wilayah Kerja Puskesmas Delitua

Selain memberikan pelayanan kesehatan dasar, Puskesmas Deli Tua melalui program Dirrect Observed Treatment Shot Course (DOTS) memberikan pelayanan pemberantasan tuberkulosis. Gambaran Kasus TB di wilayah 
kerja Puskesmas Deli Tua dapat dilihat seperti pada grafik gambar 3 berikut ini.

Dari gambar 3 dapat dilihat bahwa terjadi peningkatan jumlah kasus TB baru ternotifikasi dari bulan Juli-Agustus tahun 2018 dan menurun hingga bulan Oktober 2018 baik untuk kasus laki-laki maupun perempuan. Kemudian dari bulan Oktober terjadi peningkatan secara drastis jumlah kasus TB ternotifikasi pada bulan Januari tahun 2019 dan kembali mencapai puncaknya pada bulan Mei 2018.

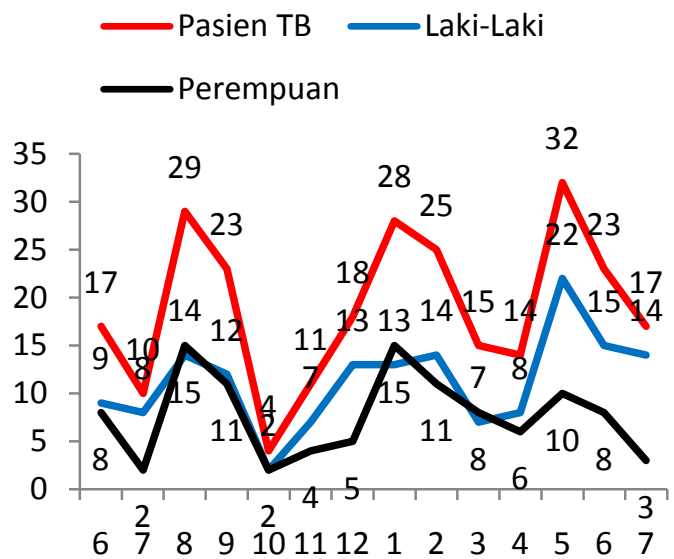

Tahun 2018-2019

\section{Gambar 3. Gambaran Kasus Tuberculosis di} Puskesmas Deli Tua Tahun 2019

Sumber: Data DOTS Program Penanggulangan TB Puskesmas Deli Tua

Profil individu kasus TB dalam laporan ini difokuskan pada analisa usia, jenis kelamin, status perkawinan, jumlah anak, pekerjaan, pendidikan, dan tingkat pendapatan. Gambaran analisis profil individu kasus TB dalam dapat dilihat seperti pada tabel 1 berikut ini.

Tabel 1.

Karakteristik Individu Kasus TB di Puskesmas

\begin{tabular}{llll}
\hline \multirow{2}{*}{ No } & \multirow{2}{*}{ Variabel } & \multicolumn{2}{c}{ Kasus TB } \\
\cline { 3 - 4 } & & $\mathbf{n}$ & $\mathbf{\%}$ \\
\hline \multirow{3}{*}{1} & Usia (tahun) & 12 & 12,1 \\
2 & $\leq 20$ & 37 & 37,4 \\
3 & $21-40$ & 50 & 50,5 \\
\hline \multicolumn{2}{r}{ Jumlah } & 99 & 100 \\
\hline
\end{tabular}

\begin{tabular}{|c|c|c|c|}
\hline \multirow{2}{*}{ No } & \multirow{2}{*}{ Variabel } & \multicolumn{2}{|c|}{ Kasus TB } \\
\hline & & $\mathbf{n}$ & $\%$ \\
\hline & Jenis Kelamin & & \\
\hline 1 & Laki-laki & 58 & 58,6 \\
\hline \multirow[t]{3}{*}{2} & Perempuan & 41 & 41,4 \\
\hline & Jumlah & 99 & 100 \\
\hline & Status Kawin & & \\
\hline 1 & Kawin & 76 & 76,8 \\
\hline \multirow[t]{3}{*}{2} & Tidak kawin & 23 & 23,2 \\
\hline & Jumlah & 99 & 100 \\
\hline & $\begin{array}{l}\text { Pendapatan / Bulan } \\
\text { (dalam Juta Rupiah) }\end{array}$ & & \\
\hline 1 & $<2,5$ & 83 & 83,8 \\
\hline 2 & $2,5-5$ & 15 & 15,2 \\
\hline \multirow[t]{2}{*}{3} & $>5$ & 1 & 1 \\
\hline & Jumlah & 99 & 100 \\
\hline
\end{tabular}

Dari tabel diatas dapat dilihat bahwa usia keluarga kasus TB di wilayah kerja Puskesmas Deli Tua lebih banyak ditemukan pada kelompok usia $\geq 41$ tahun sebesar 50 dari 99 kasus $(50,5 \%)$. Kategori jenis kelamin kasus TB ditemukan lebih banyak pada jenis kelamin lakilaki sebesar 58 dari 99 kasus (58,6\%). Status perkawinan kasus TB lebih banyak dengan status kawin sebesar 76 dari 99 kasus (76,8\%). Selanjutnya, pkerjaan kasus TB paling banyak ditemukan dengan kategori tidak bekerja sebesar 36 dari 99 kasus (36,4\%), tingkat penghasilan kasus TB paling banyak ditemukan pada kategori tingkat pendapatan $\leq 2,5$ juta sebesar 83 dari 99 kasus (83,8\%).

Analisa terhadap outcome dari intervensi pemetaan kasus TB berbasis google earth menunjukan adanya perbedaan tingkat kelengkapan (kepatuhan), kesembuhan, angka drop out dan angka kematian kasus TB sebelum dan sesudah intervensi pemetaan kasus TB berbasis google earth. Gambaran outcome pemetaan kasus TB berbasis google earth di wilayah kerja Puskesmas deli Tua dapat dilihat seperti pada tabel 2 berikut.

Tabel 2 menunjukkan bahwa program pemetaan kasus TB berbasis google earth terhadap kepatuhan minum obat ditemukan lebih tinggi sesudah pemetaan kasus TB berbasis google earth $(84,8 \%)$ dibandingkan sebelum pemetaan kasus TB berbasis google 
earth (66,5\%). Tingkat kesembuhan pasien TB juga lebih tinggi ditemukan sesudah pemetaan kasus TB berbasis google earth $(81,8 \%)$ dibandingkan sebelum pemetaan kasus TB berbasis google earth $(65,9 \%)$. Angka drop out dari pengobatan lebih tinggi sebelum pemetaan kasus TB berbasis google earth $(28,7 \%)$ dinbandingkan dengan sesudah pemetaan kasus TB berbasis google earth (16,2\%\%). Angka kematian juga menunjukan hal yang sama dimana ditemukan lebih tinggi sebelum pemetaan kasus TB berbasis google earth $(5,4 \%)$ dibandingkan sesudah pemetaan kasus TB berbasis google earth (1\%).

Tabel 2.

Gambaran Efektifitas Intervensi Pemetaan Kasus TB Berbasis Google Earth

\begin{tabular}{llcccc}
\hline No & Variabel & \multicolumn{2}{c}{$\begin{array}{c}\text { Sebelum } \\
\text { Program } \\
\text { Google Earth }\end{array}$} & \multicolumn{2}{c}{$\begin{array}{c}\text { Sesudah } \\
\text { program } \\
\text { Google Earth }\end{array}$} \\
\cline { 3 - 6 } & & $\mathrm{n}$ & $\%$ & $\mathrm{n}$ & $\%$ \\
\hline & $\begin{array}{l}\text { Kelengkapan } \\
\text { Pengobatan }\end{array}$ & & & & \\
1 & Tidak Patuh & 56 & 33,5 & 15 & 15,2 \\
2 & Patuh & 111 & 66,5 & 84 & 84,8 \\
\hline & Jumlah & 167 & 100 & 99 & 100 \\
\hline & Kesembuhan & & & & \\
1 & Tidak sembuh & 57 & 34,1 & 18 & 18,2 \\
2 & Sembuh & 110 & 65,9 & 81 & 81,8 \\
\hline & Jumlah & 167 & 100 & 99 & 100 \\
\hline & Drop Out & & & & \\
1 & Drop Out & 48 & 28,7 & 16 & 16,2 \\
2 & Tidak drop Out & 119 & 71,3 & 83 & 83,8 \\
\hline & Jumlah & 167 & 100 & 99 & 100 \\
\hline & Meninggal & & & & \\
\hline 1 & Meninggal & 9 & 5,4 & 1 & 1 \\
2 & Tidak meninggal & 158 & 94,6 & 98 & 99 \\
\hline & Jumlah & 167 & 100 & 99 & 100 \\
\hline
\end{tabular}

\section{Monitoring Kasus Tuberculosis}

Monitoring kasus tuberculosis dilakukan dari waktu ke waktu. Data diimput dari dokumentasi kalender yang dikumpulkan oleh pasien TB sekali dalam sebulan. Setiap bulan pergerakan kasus di analisis apakah terjadi perubahan risiko atau tidak. Jarak kasus ke puskesmas juga dilakukan pengukuran dalam maping. Keterangan profil kasus juga ditambahkan jika dianggap penting seperti foto rumah, lingkungan rumah, kamar tidur, dan kondisi penghuni rumah lainnya. Gambaran kasus tuberculosis di wilayah kerja Puskesmas Delitua dalam pemetaan kasus TB berbasis google earth dapat dilihat seperti gambar berikut.

Gambar 4 di berikut menunjukan bahwa monitoring kasus tuberculosis dalam bulan ke 6 program berjalan menunjukan convergensi kasus tidak berisiko, berisiko rendah, dan berisiko tinggi untuk menularakan tuberculosis. Dari gambar juga dapat diketahui bahwa jarak kasus terdekat ke puskesmas adalah 0,5 km dan jarak terjauh adalah 6,5 km. Gambaran kasus berisiko tinggi dan berisiko rendah dalam pemetaan kasus TB berbasis google earth dapat di visit dengan segera oleh petugas TB untuk dilakukan pemeriksaan TB MDR dan memberikan edukasi untuk mempercepat penyembuhan tuberculosis.

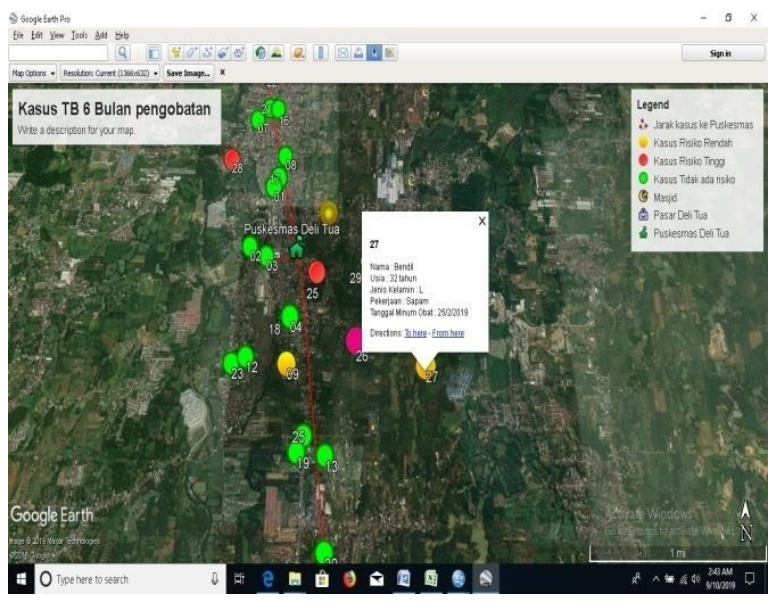

Gambar 4. Monitoring KasusTuberculosis Berbasis Google Earth

Selain menunjukan status, lokasi, dan jarak kasus ke puskesmas monitoring kasus TB berbasis google earth juga dapat digunakan untuk melihat sarana dan prasarana transportasi di wilayah kerja puskesmas. Salah satu kendala yang terjadi pada kasus TB tidak mengambil obat tepat waktu adalah medan lokasi sarana transportasi yang jauh dan kondisi jalan yang sulit dilalui oleh kendaran. Bila dilihat dari 
kondisi sarana transportasi di wilayah kerja puskesmas Deli Tua dari pemetaan kasus TB berbasis google earth, medan lokasi memiliki sarana transportasi yang sangat memadai dan mudah untuk di jangkau.

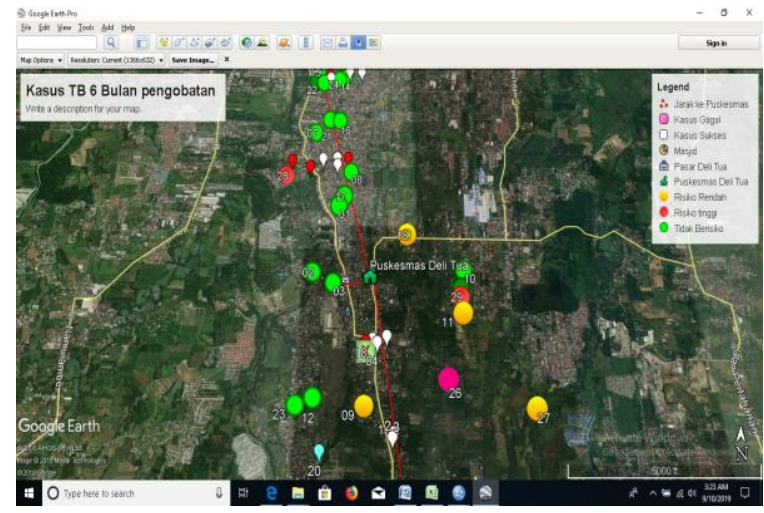

Gambar 5. Gambaran Monitoring Kasus TB Berbasis Google Earth

Dari gambar diatas dapat dilihat bahwa dot putih adalah kasus sembuh untuk periode program tahun sebelumnya yaitu tahun 2018. Dot merah menggambarkan pasien TB gagal kasus yang tidak ditangani, dot abu-abu adalah kasus TB tahun 2018 yang terdiagnosis TB MDR. Dengan adanya keterangan kasus ini penularan kasus TB dapat diprediksi di masa yang akan datang. Jika kasus baru muncul dari lokasi kasus lama yang ada (misalnya TB MDR) maka kasus baru tersebut dapat di prediksikan merupakan kasus baru TB MDR.

\section{Efektifitas Penerapan Monitoring Kasus TB Berbasis Google Earth}

Efektifitas penerapan google earth diukur dengan menggunakan outcome program pengobatan tuberculosis yang meliputi kelengkapan pengobatan, tingkat kesembuhan, angka drop out, dan angka kematian. Perbedaan outcome program maping pencegahan penularan tuberculosis berbasis google earth sebelum dan sesudah intervensi dapat dilihat seperti pada table berikut

Tabel 3. Hasil Analisi Efektifitas Program

Dengan Menggunakan MC Nemar Test

\begin{tabular}{llll}
\hline Variabel & p- MC & Risiko & $95 \% \mathrm{CI}$ \\
& Nemar & relative (RR) & \\
& &
\end{tabular}

\begin{tabular}{llll}
\hline $\begin{array}{l}\text { Kelengkapan } \\
\text { pengobatan }\end{array}$ & 0,001 & 2,21 & $1,32-3,69$ \\
$\begin{array}{l}\text { Tingkat } \\
\begin{array}{l}\text { Kesembuhan } \\
\text { Drop out }\end{array}\end{array}$ & 0,001 & 1,87 & $1,17-2,99$ \\
Angka Kematian & 0,001 & 1,77 & $1,07-2,95$ \\
\hline
\end{tabular}

Penerapan program pencegahan penularan tuberculosis berbasis google earth menunjukan perbedaan yang bermakna kelengkapan pengobatan sebelum dan sesudah intervensi $(p<0,01)$ dengan $R R=2,21 ; 95 \% C I$ : 1,32-3,69. Tingkat kesembuhan pasien juga ditemukan berbeda bermakna sebelum intervensi dan sesudah intervensi $(p<0,01)$ dengan $\mathrm{RR}=1,87 ; 95 \% \mathrm{CI}: 1,17-2,99$. Hal yang sama juga ditemukan pada angka drop out pasien dari pengobatan yang menunjukan perbedaan yang bermakna sebelum dan sesudah intervensi $(p<0,01)$ dengan $R R=1,77$; 95\%CI: 1,07-2,95. Angka kematian juga menunjukan perbedaan yang bermakna sebelum dan sesudah intervensi $(p<0,01)$, namun belum menunjukan angka risiko yang bermakna secara statistik.

Program kemitraan masyarakat (PKM) yang telah dilakukan selama 6 bulan dengan menerapkan teknologi google earth dalam memonitoring kasus tuberculosis di Puskesmas Deli Tua (kelompok intervensi) telah memberikan hasil. Meskipun hasil ini, belum memberikan gambaran yang maksimal tentang efektifitas program, namun indikasi ini telah menunjukan bahwa pemetaan kasus tuberculosis berbasis google earth telah memberikan peranan penting dalam pengembangan sistem monitoring kasus tuberculosis di Indonesia.

Pemetaan kasus tuberculosis berbasis google earth adalah pemetaan kasus tuberculosis dengan menggunakan software google earth. Software ini sangat efektif untuk memetakan kasus secara individual dalam wilayah yang sempit (seperti puskesmas) terutama untuk kasus-kasus penyakit menular. Hal ini disebabkan kasus penyakit menular pada 
dasarnya dalam keadaan endemis di satu wilayah kerja puskesmas hanya berkisar antara 1-200 kasus dalam 1 tahun. Dengan jumlah kasus yang demikian, peta dot spot map sangat baik dilakukan sehingga profil kasus tertentu seperti umur, jenis kelamin, pendapatan, dan kondisi lingkungan dapat di pantau dengan cukup baik (WHO, 2016).

Berbeda dengan sistem pemetaan GIS (Geografic Information System), sistem pemetaan berbasis google earth tidak perlu menggunakan safe file. Hal ini tentu menguntungkan penguna peta google earth yang tidak perlu mengubah safe file tertentu jika terjadi pemekaran wilayah tertentu. Oleh karena itu, penggunaan pemetaan tuberculosis berbasis google earth tidak membutuhkan keahlian khusus. Petugas puskesmas yang berlatar belakan pendidikan kesehatan mampu mengoperasikan pemetaan kasus tuberculosis berbasis google earth dengan terlebih dahulu mendapatkan pelatihan.

Monitoring kasus tuberculosis dilakukan selama 1 periode pengobatan yaitu 6 bulan. setelah 6 bulan seorang kasus yang lengkap menjalani pengobatan (dot hijau) dan sembuh melalui pemeriksaan laboratorium maka warna kasus berubah jadi putih. Namun jika proses pengobatan tidak dilakukan dengan lengkap, maka warna kasus merah bulat, berubah menjadi merah lonjong. Titik merah lonjong menunjukan bahwa kasus tuberculosis adalah kasus tuberculosis MDR atau tuberculosis laten di populasi.

Jarak terdekat dan terjauh kasus dari puskesmas juga perlu dipetakan dalam peta. Hal ini dilakukan untuk memahami apakah faktor jarak ke puskesmas berkontribusi terhadap ketidak lengkapan (kepatuhan) pengobatan. Selain itu, pemetaan juga memperlihatkan kepadatan rumah dalam suatu wilayah tertentu dan kondisi lingkungan pemukiman. Faktorfaktor ini berkontribusi terhadap penularan tuberculosis di populasi (Mackey, 2016).
Pemetaan kasus tuberculosis juga memberikan gambaran sumber penularan dalam populasi. Jika program tahun lalu kasus tuberculosis tidak sembuh dalam populasi dan tahun ini atau tahun yang akan datang dari lokasi kasus muncul kasus baru tuberculosis, maka dapat diduga sementara bahwa kasus tersebut adalah tb MDR (Adamou, 2014). Dengan informasi ini, paisen tuberculosis baru tersebut dapat direkomendasikan untuk pemeriksaan tuberculosis MDR sebelum dilakukan pengobatan. Yang terjadi selama ini adalah petugas DOTS berpatokan pada hasil pemeriksaan sputum laboratorium. Jika hasil laboratorium puskesmas menunjukan sputum + maka akan langsung diberikan pengobatan tuberculosis dengan dosis kasus baru (WHO, 2016). Dalam hal kasus tuberculosis memang adalah kasus baru, tentu tidak ada masalah. namun jika kasus adalah MDR maka dengan pengobatan 6 bulan yang diberikan tidak akan berdampak pada kesembuhan kasus. Dengan demikian, kesalahan dosis pengobatan karena salah diagnosa dapat dihindari.

Dari hasil uji statistik menunjukan terdapat perbedaan kelengkapan pengobatan sebelum dan sesudah intervensi program pemetaan kasus tuberculosis berbasis google earth dengan peningkatan kelengapan pengobatan sebesar $18,3 \%$. Hal ini menunjukan bahwa tingkat efektifitas intervensi pemetaan kasus tuberculosis berbasis google earth terhadap kelengkapan pengobatan. Kelengkapan pengobatan ini disebabkan karena adanya motivasi kasus tuberculosis untuk sembuh. Motivasi ini muncul karena pengaruh pengisisan dokumentasi kalender sebagai salah satu alat self-monitoring kausus tuberculosis.

Selain itu, hasil penelitian juga menunjukan bahwa terdapat perbedaan kesembuhan kasus tuberculosis sebelum dan sesudah intervensi pemetaan berbasis google earth dengan peningkatan tingkat kesembuhan mencapai $15,9 \%$. Peningkatan ini tidak terlepas 


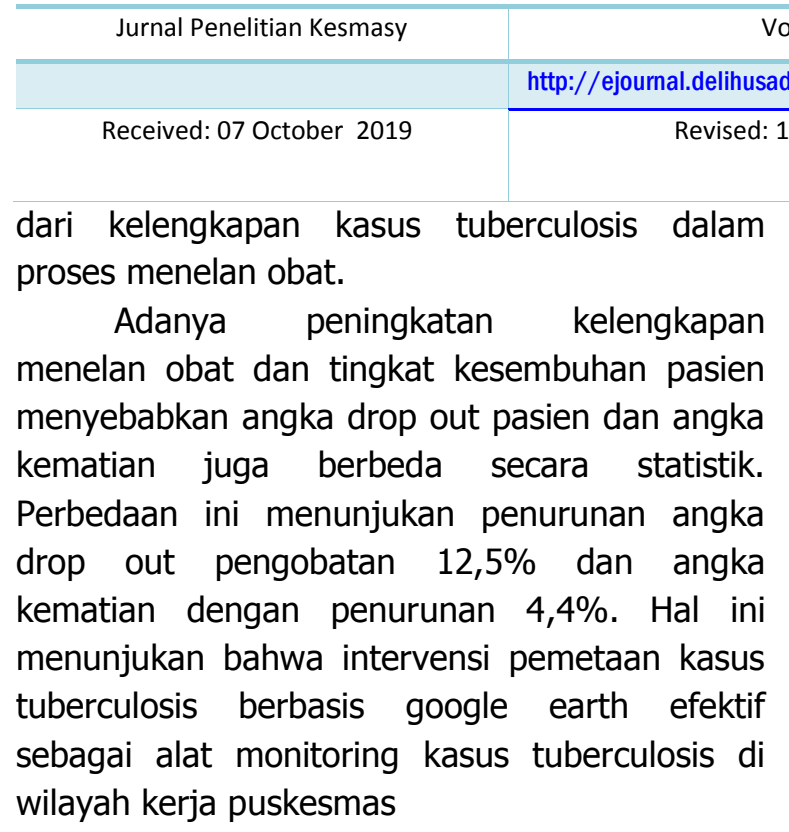

\section{KESIMPULAN}

Efektifitas intervensi pemetaan kasus tuberculosis berbasis google earth berbeda bermakna dalam kelengkapan pengobatan dan meningkat sebesar $18,3 \%$, tingkat kesembuhan juga berbeda bermakna sebelum dan sesudah intervensi dan meningkat sebesar $15,9 \%$, angka drop out pengobatan ditemukan berbeda bermakna sebelum dan sesudah intervensi dengan peningkatan 12,5\%. Intervensi pemetaan kasus tuberculosis berbasis google earth menurunkan angka kematian kasus sebesar $4,4 \%$.

\section{DAFTAR PUSTAKA}

Adamou B,. 2014, GIS for Monitoring Scale, MEASURE Evaluation PRH; USA: University Of North Carolina.

Athena D, Anwar M, 2014, Penelitian Pengembangan Model Sistem Surveilans Dampak Kesehatan perubahan Iklim, Blutin Penelitian kesehatan; 42: 46-58

CDC, 2014, Patient Adherence to Tuberculosis
Vol. 2 No. 1

Edition: May - October 2019

Accepted: 22 October 2019

Treatment. Departement of health and Human Services Public Health Service, Atlanta, Georgia

Dinas Kesehatan, 2017, Profil Kesehatan Kabupaten Deli Serdang Tahun 2017. Dinas Kesehatan Deli Serdang, Deli Serdang; 1:64-69

Green DS, Jaser S, Whittemore R,. 2013, Processes of Self-Management in Chronic Illness. PMC; 44: 136-144

Ho Lin, H, Sonya S. Shin, Contreras C, Asencios L, Christopher J. Paciorek, and Cohen T. 2012, Use of Spatial Information to Predict Multidrug Resistance in Tuberculosis Patients. Emerging Infectious Diseases; 18; 5: 811-813. www.cdc.gov/eid

Mackey LM, Doody C, Warner EL, Fullen B,. 2016, Self-Management Skill in Chronic desease Management: What Role Does Health Literacy Have. Pub Med; 36: 74159

Martin, L,. Williams, S,.Haskard, K,.DiMatteo, R,. 2015; The Challenge of Patient Adherence, Department of Psychology, La Sierra University, CA, USA; 2Department of Psychology, University of California, Riverside, CA, USA.

Petricia A, Grady RN, Gough LL. 2014, SelfMangement: A Comprehensive Approach to Mangement of Chronic Condition. American Journal Of Public Health; 104: e25e31

WHO, 2016; Global Actions and Investments Fall Far Short of Those Needed to End the Global TB Epidemic. Global Tuberculosis Report. Janeva

WHO, 2017; TB Burden Estimate, Notification and Treatment Outcome. WHO. Janeva 